\section{THE IMPACT OF SELECTED FACTORS AFFECTING STU- DENTS ENTREPRENEURIAL INTENTIONS}

\section{INTRODUCTION AND LITERATURE REVIEW}

Entrepreneurship involves job creation, poverty alleviation, innovation, and societal prosperity (1). The creation of new enterprises is considered essential for the development of national economies (2). Identifying the determinants of entrepreneurship is the first step in establishing and implementing entrepreneurial policies and the subsequent calculation of their social and economic impact (3). Starting a new business is considered an intentional act, and entrepreneurial intention is regarded as the most immediate and robust predictor of entrepreneurs' future behavior (4);(5). Entrepreneurial intentions are essential for understanding the entrepreneurial process as it is the first step in discovering, creating, and exploiting opportunities. Based on the social cognitive approach, Ajzen's theory postulates that intention predicts human behavior, determined by a person's attitude towards behavior and social support provided in this approach (6). Entrepreneurial intention plays an important role in understanding the association between an individual and a new business (4). Some of the earliest studies related to entrepreneurship investigated personal traits and their relationship to business creation (7). Therefore, the personality traits of individuals are considered significant for new venture creation and entrepreneurship (8). A series of psychological studies on entrepreneurial attitude focused primarily on identifying the reasons behind the decisions to become an entrepreneur and the personality traits of entrepreneurs. Entrepreneurial personality is defined by a set of personal characteristics or traits specific to entrepreneurs (i.e., desire for
DOI: $10.5937 / \operatorname{Rev} 2092069 S$

\section{SUMMARY}

Key words: Entrepreneurial intentions, Education, International mobility, personal traits.

Entrepreneurs can be defined as the key actuator of economic growth and an essential factor for societal prosperity. Entrepreneurship is promoted as a career option among young people, and the intention to become entrepreneurs can be influenced by psychological, socio-demographic, and educational factors. This paper examines the impact of personality traits, family background, and international education mobility on students' entrepreneurial intention. A questionnaire was used in the study as the research instrument. Results of the quantitative analysis show a significant impact of selected factors on entrepreneurship intentions. 
achievement, self-confidence, locus of internal control, desire for autonomy, inclination to take risks, creativity, and tolerance ambiguity) (9). According to previous studies, personality traits are important antecedents of intention and positively influence business start-up (10). Mendoza and Lacap observed that creative personality traits increase entrepreneurial intentions (11).

Regarding the family background, entrepreneurs are strongly influenced by parental model and family support in continuing their entrepreneurial activities (12). Family background can influence intentions by impacting the individual's career preference intentions (i.e., attitude, subjective norms, and perceived behavioral control) (13). Ac-

Creative personality traits increase entrepreneurial intentions. cording to Mustapha and Selvaraju, the parental model is an essential factor motivating students toward entrepreneurship (14). Numerous authors found that social influence through family background is a crucial determinant of entrepreneurial career decisions (4);(15). Moreover, the power of existing family background on entrepreneurial intention can, directly and indirectly, affect the following variables: attitude towards new business, family support, and entrepreneurial self-efficacy $(16,1092)$.

Regarding the gender of the entrepreneur, Kirkwood differentiates men from women entrepreneurs through many women seek parental support and encouragement for entrepreneurship, while men are more independent. $(17,42)$

On the other hand, some authors explain that "a self-employed father increases the likelihood of children becoming entrepreneurs in the future." (18) Entrepreneurship is also promoted as a career option among young people. Several authors have shown that the intention to become entrepreneurs can be influenced by psychological, socio-demographic, and educational factors. In turn, education fulfilled the role of a leading factor in the development of young people's personalities. Bakotić and Kružić consider university institutions important for developing entrepreneurial behavior (19);(20).

An entrepreneurial attitude is influenced by intensive, entrepreneurship education programs (21). A positive relationship exists between entrepreneurial education and entrepreneurial mindset (22). Several empirical studies emphasize the positive influence of education on entrepreneurship and represent it as a significant predictor in intention formation (23);(24);(25). Boissin et al. confirms the positive impact of education and concludes that entrepreneurship education programs should be designed and targeted according to the student profiles. Entrepreneurship education is focused on developing entrepreneurial skills and knowledge (1). 
The experience of studying abroad is a uniquely personal opportunity, which can become appealing for different reasons and not just the professional side. Personal enrichment, learning new languages, contacting people from different cultures, confrontation with the unknown, and other factors are essential tools for the growth of individuals throughout the academic and professional journey. According to Souto-Otero and McCoshan, students reported that the international mobility program had a positive impact on attitudes regarding aspirations and career (28);(29). Bryla specifies that the exchange program's main benefits are independence, foreign language, intercultural skills, and self-confidence (30). It was noted in the literature that completing studies abroad helps students in increasing chances for an active role in the labor market and affects students' personality. This research examined the relationship between the entrepreneurial intention of international students and their personality traits, family background, and international mobility education. It was performed at the Institute of Business Administration in Nice (IAE Nice).

\section{METHODOLOGY}

This paper presents quantitative research on a limited data sample $(\mathrm{N}=25)$ performed at IAE. Questionnaires have been conducted at international exchange students who arrived at IAE during the 2019-2020 academic year. Students' origins were from a variety of countries. The questionnaire contained 11 questions regarding entrepreneurial intentions and factors affecting them. The plan was to collect data samples for multiple years to perform complex analysis on the more extensive data set, including time-series variations. For this paper, we have prepared an analysis of one academic year data set. This study's participants are students who have benefited from the scholarship of international mobility program at the Institute of Business Administration during the mentioned academic year. Out of the total sample, $72 \%$ were female students and $28 \%$ male students from the total number of students. The students with missing data were excluded from the study. The research approach is a quantitative method as questionnaires have been distributed to international exchange students to conclude the factors influencing their entrepreneurial intention. The method used in the research context was hrough data collection, analysis, and interpretation of results. The primary data were analyzed using R Studio 1.2.0, open-sourced, professional software for data science. 


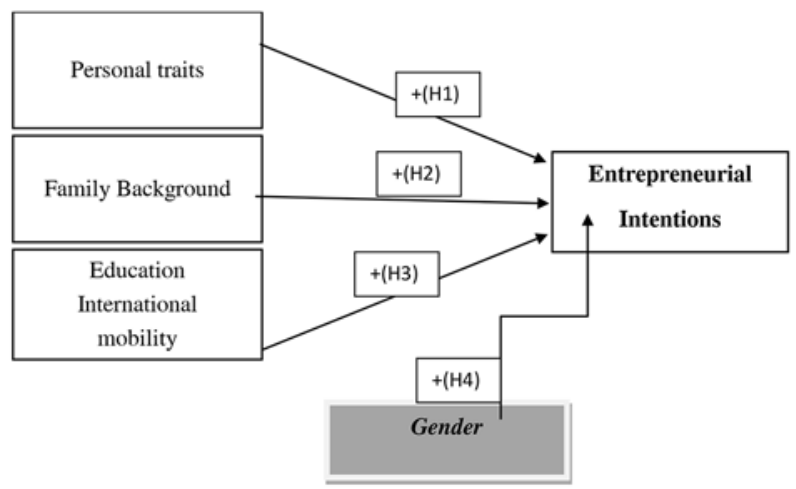

Figure 1. Conceptual Framework

Conceptual Framework is based and adapted from the Ajzen's Theory of Planned Behaviour trough which will analyze the relationship between factors (family background, personality traits, and education international mobility) and entrepreneurial intention of international students (31). These selected factors are tested in this research as per the defined conceptual Framework. Also, the Hypothesis for this research have been developed as follows:

Hypothesis H1: If personality traits were assessed as modified in entrepreneurship direction through students' mobility program, the entrepreneurial intention would likely increase.

Hypothesis H2: If family background shows the history of entrepreneurship, the entrepreneurial intention will likely increase.

Hypothesis H3: If education international mobility impact on entrepreneurial attitudes is higher, entrepreneurial intentions will likely increase.

Hypothesis H4: If gender is male, the entrepreneurial intention will likely increase.

For the first section of data analysis, descriptive statistics were used to explain ratio and group characteristics. In addition, the data set was prescribed within a Microsoft Excel spreadsheet and added to " $\mathrm{R}$ " software for data analysis. Due to the data set, a size-independent t-test was selected as the statistical method within the quantitative analysis. The assumption was that normal distribution is present in the data sets, that two groups are independent, and we would prefer to understand means differences-equalities among observed groups. Also, we applied unequal variances and the Welsh test. We considered a two-tailed function when means are different, but the direction isn't pre-assumed. Codification of variables in $\mathrm{R}$ was done in the following way: Entrepreneurial intentions (EI); Personality treats (PT); Family background (FB); Education International mobility (IM) (same codification will be used in the further text 
for names of variables). Below is an example of the syntax used in " $R$ " software for data analysis:

$$
\begin{gathered}
\text { “attach(dataset. data=data) } \\
\text { view (dataset) } \\
\text { x=EI; } y=\text { Gender } \\
\text { t.test }(\mathrm{x}, \mathrm{y}) \\
\text { var.equal=TRUE } \\
* * * \\
\text { attach(dataset. data=data) } \\
\text { wilcox.test(EI } \sim \text { Gender, data=data) } \\
\text { plot(data)" }
\end{gathered}
$$

Following data input, we received significant results of the observed variables, which will be explained in the following section.

\section{DISCUSSION}

The descriptive statistics were used to gain information about the respondents' gender, age, education background (52\% bachelor level, $44 \%$ masters level students, and $4 \%$ doctoral students), family background, personality traits, and impact of international mobility. In terms of respondents' age, $72 \%$ were between $19-23$ years, $20 \%$ were between $24-30$ years, and $2 \%$ were more than 30 . The gender structure is listed in the following Table 1.

Table 1. Gender of participants (ratio-structure)

\begin{tabular}{llcccc}
\hline Gender & & & & \\
\hline \multirow{3}{*}{ Valid } & Frequency & Percent & Valid Percent & $\begin{array}{c}\text { Cumulative } \\
\text { Percent }\end{array}$ \\
\cline { 3 - 6 } & Female & 7 & 28.0 & 28.0 & 28.0 \\
& Total & 25 & 72.0 & 72.0 & 100.0 \\
\hline
\end{tabular}

Table 2. Descriptive statistics

\section{Descriptive Statistics}

\begin{tabular}{lccc}
\hline & N & Mean & Std. Deviation \\
\hline Age & 25 & 1.3600 & .63770 \\
Gender & 25 & 1.7200 & .45826 \\
Education & 25 & 1.5200 & .58595 \\
Family Background & 25 & 1.5200 & .50990 \\
Personal traits & 25 & 4.6400 & 2.23383 \\
International mobility & 25 & 3.4800 & 1.29486 \\
Entrepreneurial intentions & 25 & 1.3200 & .47610 \\
Valid N (listwise) & 25 & & \\
\hline
\end{tabular}


The main factors that influenced the student's desire to go abroad are the curiosity to find out what is studied in another country, academic and professional opportunities, academic training, and the interest to live in another country. Other authors found motivational factors like a new foreign environment, European experience, educational opportunities, career planning, and friendship (31).

The quantitative analysis (t-test) in " $R$ " shows the high significance of the correlation of observed variables. Namely, for considering variables of EI and Gender, Welch two-sample t-test show p-value as 0.003971 , on a 95 confidence interval with 47 degrees of freedom. Considering variables EI and IM, p-value was 8.988e-09)with 95 percent confidence interval; for variables, EI and PT result shown $p$-value $=9.78 \mathrm{e}-08$ with 95 percent confidence interval. All observed factors are considered as highly significant.

\section{CONCLUSION}

The results of this research show that factors of gender, personal treats, and international mobility in education have significant affection for the entrepreneurial intentions of the students' population. On the other hand, hypothesis $\mathrm{H} 2$ (where we observe affection of the family background in entrepreneurship on the next generation entrepreneurial intentions) was rejected due to minor results insignificance after performing t-test via " $R$ ". The other 3 Hypothesis have been confirmed, and the significant impact of observed factors have been shown through quantitative analysis. This might be understood as a possibility that students who have undergone international mobility education programs are highly likely to develop stronger entrepreneurial intentions. This also makes those students more employable. Personal traits are affected by international mobility, and international students showed satisfaction by the host university at the level of $76 \%$. Also, their attitudes towards entrepreneurship have been changed and were verified at the level of $80 \%$. This research contributes to previous research in entrepreneurial intentions confirming affection of selected determinants and showing direction for the universities to include more international students, offer more relevant courses within curricula, and work more on developing required skills at students to achieve better entrepreneurial results for the student's population. Research limitations are seen mostly in the data set size. Therefore for further research, we are proposing to have a higher number of participants and greater variety among educational backgrounds. 


\section{LITERATURE}

1. Liñán, F., Rodríguez-Cohard, J. C., \& Rueda-Cantuche, J. M. (2011). Factors affecting entrepreneurial intention levels: A role for education. The International Entrepreneurship and Management Journal, 7(2), 195218.

2. Fayolle, A., Verzat, C. and Wapshott, R. (2016), In quest of legitimacy: The theoretical and methodological foundations of entrepreneurship education research, International Small Business Journal, 34 (7), 895904

3. Rusu S., Isac F., Cureteanu R., Csorba L. (2012) Entrepreneurship and entrepreneur: A review of literature concepts, African Journal of Business Management Vol.6(10), pp. 3570-3575.

4. Krueger, N.F. and Carsrud, A.L. (1993), "Entrepreneurial intentions: applying the theory of planned behaviour", Entrepreneurship \& Regional Development, 5 (4), 315-330.

5. Adam, AF, Fayolle, A (2015) Bridging the entrepreneurial intention-behaviour gap: the role of commitment and implementation intention. International Journal of Entrepreneurship and Small Business 25(1): 36-54.

6. Ajzen, I. (1991). The theory of planned behaviour. Organizational Behaviour and Human Decision Processes, Organ. Behav. Hum. Decis. Process, 50 (2), 179-211.

7. McClelland, D. C., Atkinson, J. W., Clark, R. A., \& Lowell, E. L. (1953). The achievement motive. Appleton-Century-Crofts.

8. Karimi, S. (2015). Testing the relationship between personality characteristics, contextual factors and entrepreneurial intentions in a developing country. International Journal of Psychology.

9. Cromie, S. (2000). Assessing entrepreneurial inclinations: some approaches and empirical evidence. European Journal of Work and Organizational Psychology, 9 (1), 7-30.

10. Fayolle A., Linan F., and Moriano J.A. (2014) Beyond entrepreneurial intentions: Values and motivations in entrepreneurship. International Entrepreneurship and Management Journal 10(4): 679-689.

11. Mendoza, D. B., Lacap, J. P. (2015). Personality Traits and Entrepreneurial Intentions of Business Administration Students of Selected Higher Education Institutions in Pampanga, Philippines. International Journal of Social Sciences, 1 (1), 613-631.

12. Bird, M. (2014). The Impact of the Family on Entrepreneurial Outcomes: The Role of Social Embeddedness.Stockholm School of Economics.

13. Karimi, S., et al. (2013). Understanding Role Models and Gender Influences on Entrepreneurial Intentions Among College Students. Social and Behavioral Sciences, 93

14. Mustapha, M., Selvaraju, M. (2015). Personal attributes, family influences, entrepreneurship education, and entrepreneurship inclination among university students. Kajian Malaysia, 33 (1), 155-172.

15. Bandura, A. (1977). Social Learning Theory; Prentice-Hall: Englewood Cliffs, NJ, USA, 1977; ISBN 978-0138167448.

16. Carr, J.C.; Sequeira, J.M. Prior business exposure as intergenerational influence and entrepreneurial intent: A theory of planned behavior approach. J. Bus. Res. 2007, 60, 1090-1098

17. Kirkwood, J. (2007). Igniting the entrepreneurial spirit: is the role parents play gendered? International Journal of Entrepreneurial Behaviour \& Research, 13(1), 39-59.

18. Chlosta, S., Patzelt, H., Klein, S. B., \& Dormann, C. (2010). Parental role models and the decision to become self-employed: The moderating effect of personality. Small Business Economics, 38(1), 121-138.

19. Bakotić, D., Kružić, D. (2010). Students' perceptions and intentions towards entrepreneurship: the empirical findings from Croatia. The Business Review: Cambridge,14 (2), 209-215. 


\section{UTICAJ ODABRANIH FAKTORA NA PREDUZETNIČKE INTENCIJE KOD POPULACIJE STUDENATA}

\section{REZIME}

Ključne reči: Preduzetničke intencije, obrazovanje, međunarodna mobilnost, lične osobine

Preduzetnici se mogu definisati kao ključni pokretač ekonomskog rasta i suštinski faktor društvenog prosperiteta. Među mladima se preduzetništvo promoviše kao opcija za razvoj karijere, a na nameru da postanu preduzetnici mogu uticati brojni psihološki, socio-demografski i obrazovni faktori. Ovaj rad ispituje uticaj ličnih osobina, porodičnog porekla i međunarodne mobilnosti u obrazovanju na preduzetničke intencije učenika. U istraživanju je korišćen upitnik kao instrument istraživanja. Rezultati kvantitativne analize pokazuju značajan uticaj odabranih faktora na preduzetničke intencije.
20. Ahmed T., Chandran V.G.R., Klobas J.E., Liñán F., Kokkalis P. (2020). Entrepreneurship education programmes: How learning, inspiration, and resources affect intentions for new venture creation in a developing economy. The International Journal of Management Education 18. 100327

21. Akmaliah, Z., Pihie, L., \& Bagheri, A. (2010). Entrepreneurial attitude and entrepreneurial efficacy of technical secondary school students. Journal of Vocational Education \& Training, 37-41.

22. Yaqub, M., Mufti, N., Ali, S., \& Khaleeq, M. (2015). Impact of Entrepreneurship Education on Attitudes of Students Towards Entrepreneurship. Journal of Basic and Applied Sciences, 11, 590-595

23. Küttim, M., Kallastea, M., Venesaara, U., Kiis, A. (2014). Entrepreneurship education at university level and students'entrepreneurial intentions. Procedia - Social and Behavioral Sciences, 110, 658-668.

24. Liu, X., Lin, C., Zhao G., Zhao D. (2019) Research on the Effects of Entrepreneurial Education and Entrepreneurial Self-Efficacy on College Students' Entrepreneurial Intention. Front. Psychol. 10 (869), 1-9.

25. Luthje, C. , Franke, N. (2003). The 'making' of an entrepreneur: testing a model of entrepreneurial intent among engineering students at MIT. R\&D Management, 33 (2), 135-147.

26. Boissin, Favre-Bonté, Fine Falcy (2017). Diverse impacts of the determinants of entrepreneurial intention: three submodels, three student profiles. Revue de l'Entrepreneuriat, DeBoeck Supérieur, 16 (3-4), 17-43.

27. Boissin, Favre-Bonté, Fine Falcy (2017). Diverse impacts of the determinants of entrepreneurial intention: three submodels, three student profiles. Revue de l'Entrepreneuriat, DeBoeck Supérieur, 16 (3-4), 17-43.

28. Souto-Otero, M., \& McCoshan, A. (2006). Survey of the Socio-Economic Background of ERASMUS Students. Final report to the European Commission. European Commission

29. Farrugia, C., \& Sanger, J. (2017). Gaining an Employment Edge: The Impact of Study Abroad on 21st Century Skills \& Career Prospects in the United States. Washington, DC: IIE Center for Academic Mobility Research and Impact.

30. Bryla, P. (2014). Self-Reported Effects of and Satisfaction with International Student Mobility: A Large-Scale Survey among Polish Former Erasmus Students. Procedia - Social and Behavioral Sciences, 191, 2074-2082

31. Ajzen, I. (2002). Perceived behavioral control, self-efficacy, locus of control and the theory of planned behavior. Journal of Applied Social Psychology, 32 (4), 665-683 